\title{
Storytelling and Social Networking as Tools for Digital and Mobile Marketing of Luxury Fashion Brands
}

\author{
https://doi.org/10.3991/ijim.v11i6.7511 \\ Zahaira Fabiola González Romo( $\left.{ }^{\varpi}\right)$ \\ Universitat Internacional de Catalunya, Barcelona, Spain \\ zfgonzalez@uic.es \\ Irene García-Medina \\ Glasgow Caledonian University, Glasgow, United Kingdom \\ Noemí Plaza Romero \\ Universitat Oberta de Catalunya, Barcelona, Spain
}

\begin{abstract}
This research intends to discover what the current strategies in digital marketing that are being carried out by brands in the luxury fashion sector are. It is intended to identify the most relevant aspects in the interaction of brands with their audiences in a digital and mobile environment, for which qualitative techniques have been used, through content analysis and in-depth interviews. We have found that, among others, the principle of "storytelling" is one of the key strategies in digital marketing, this principle is found in video marketing strategies, social media, events and exhibitions open to the public, which seek to interact with public and show its history.
\end{abstract}

Keywords-Marketing strategies, mobile marketing, social networks, bloggers, storytelling, marketing trends, influencers, interactivity, interaction.

\section{Introduction}

New technologies have been a challenge for all sectors, forcing marketers to rethink the most appropriate ways to reach increasingly younger audiences who are much more accustomed to the use of mobile devices and interaction with brands. The production of luxury goods is sometimes guided by multi-brand strategies in large companies that do not always take into account what is a priority for their consumers. Beverland [1] argues through his research that the luxury brand is based on trends, culture, history, product integrity, commercialization and support. However, in some cases it is the design and not the brand which is important in the marketing of luxury items.

Luxury brands have reinvented their marketing and business strategies to adapt and approach emerging markets eager to consume luxury fashion, which is why digital marketing becomes an essential tool for the communication of leaders luxury brands with their audiences, especially the younger ones [2] and although many of them still resist the sale online considering as a path not adapted to the criteria of the luxury 
Paper-Storytelling and Social Networking as Tools for Digital and Mobile Marketing of Luxury Fash..

experience, digital marketing becomes important in each of their strategies, helping in brand awareness, consumer interaction and purchase motivations [2].

\section{Methodology}

The present research intends to know what are the current strategies in digital and mobile marketing that are being carried out by the brands of the luxury fashion sector. The intention is to identify the most relevant aspects in the communication of brands to their audiences in a digital and mobile environment, for which qualitative techniques have been used in the methodology, through content analysis and in-depth interviews.

The selection of the brands analyzed was carried out taking into account the results of the Brandz 2015 ranking of Milldward Brown [3], which presents the most valued brands at international level, completing this selection with a study of the brands with more interaction in the social networks between January and June 2015 published by Digital Luxury Group (DLG) [4], these data were contrasted by the number of followers in social networks like Instagram and Facebook to arrive at a list of the brands with greater mobile interaction and followers: Prada, Chanel and Louis Vuitton.

Once the leading and filtered brands were identified through the crossing of the aforementioned data, a thorough research was carried out of their history and communication tools both offline and online and the analysis of these tools led us to describe and define their strategies by way of conclusions, helping us to do this also from the previous bibliography found on the different brands and their strategies as described in the theoretical framework of this article. To do this, we used the content analysis of both the web pages of the brands analyzed, as well as scientific articles on marketing strategies and luxury fashion, in addition to completing this research with information obtained in books, blogs and different webs specialized in luxury fashion.

Second, once the information was counted, a series of in-depth interviews were conducted with different professionals in the sector. The aim of these interviews was to complete the information obtained by the authors with the reports and the personal contributions of industry professionals in different facets of the business, in order to arrive at a clear and concise conclusion about the current situation in the marketing management of the brands of the luxury fashion sector.

\section{$3 \quad$ Literature review}

\subsection{An introduction to the concept of luxury}

There is a general agreement on the lack of "substantial" definitions of luxury. Since luxury can be defined based on the general intrinsic characteristics of the products, the techniques used or the techno-economic characteristics of the industry [5]. However, a certain consensus is emerging about the main characteristics desired by the consumer of luxury brands. The common denominators are beauty, rarity, quality 
and price [6], but also the existence of a brand of inspiration endorsing the product. In this context, brands compete for their ability to evoke exclusivity, identity, awareness and the quality perceived by consumers [7].

From a subjective point of view, the term luxury could refer to "Things you have that you do not think you should have." [8]. Most luxury products are also associated with a strong brand name and its logo, as well as a tradition of crafting and high quality [9]. Phau and Prendergast [7] emphasize the role of the brand in evoking exclusivity.

According to Phau and Prendergast [7], today's luxury products have a well-known brand identity, enjoy high brand awareness and perceived quality, and maintain customer loyalty and sales levels. Therefore, luxury objects should be recognizable, stimulate a consumer's emotional response, and be incorporated into the customer's lifestyle.

The studies by Bastien and Kapferer [2] revealed that price, quality and exclusivity were the three main concepts associated with luxury. Desire and longing were other important elements. Factors related to the value of the product such as price and cost were less central to the definition as well as the characteristics related to the "ostentatious side" of luxury goods. Sophisticated, extravagant and excessive are adjectives of this category [10].

Several researchers have enriched the traditional view of luxury consumption $[11,12,13,14]$. In this revised paradigm, two types of luxury consumption orientation (social and personal) should be considered in the management of luxury brands. Wong and Ahuvia [11] were the first to demonstrate that personal orientation towards luxury brands was more important to some consumers than to others. When these consumers choose a luxury brand, there are usually utilitarian, emotional, and symbolic dimensions that underlie their personal orientation.

\subsection{Brand Strategies}

The brand encompasses all the tangible and intangible characteristics of the company, these are the logo, name, products, employees, the environment in which the brand is involved, such as physical stores, the web and its presence in social networks, advertising, the reputation of the company and the perception of the same by the public [2]. Brand strategies are becoming increasingly one of the most important marketing strategies in the world of fashion, but in today's fancy fashion they are not only important, they have become essential. For Bastien and Kapferer [2], today luxury fashion would not exist without the brands.

The main purpose of branding strategies is to establish a clear and distinctive identity of your products, services and organization. Brand strategies also seek to create brand equity and create consumer safety. The main components with which the identity of a brand is created are: The essence of the brand, its values and its personality [2]. Brands are an integral part of the luxury product, so much so that in luxury the brand is positioned before the product. Consumers of luxury brands first choose the brand they want to purchase and then the product. 
Bastien and Kapferer [2] identify two main models of brand strategies carried out by brands that lead the luxury industry.

1. In the first model are the brands that are based on taking the quality of their products to the extreme, making a cult of them and their heritage. This is nourished by the history of the brand, its founders and its new creators, thus transmitting the personality of the brand and its values as is the case of Chanel and Hermes.

2. The second model has its origin in the United States and since it has a lack of own history, there is an invention of the history of the brand. This strategy focuses more on imagination, creativity and experimentation, thus transmitting its values. Here the brand is nourished by storytelling, as is the case of Mark Jacobs.

Once the brand is recognized by the public, as is the case of brands that lead luxury fashion, one of the most widely used strategies globally are "brand extension" and "brand stretch" [2].

The brand extension allows the company to take advantage of the power of its heritage and brand value, launching new products into new ones.

The brand extension is a very successful strategy among the brands that lead the luxury fashion, since this exploits the brand identity to the maximum. In addition, this strategy creates more visibility of the brand in the market, which contributes with more value. An example is found in Armani, with the creation of several hyper luxury resort hotels.

\subsection{Marketing strategies in Luxury Fashion}

Bastien and Kapferer [2] argue that traditional marketing strategies cannot be applied to luxury fashion so they have created the anti-laws summarized below:

a) The law of non-positioning. One of the most important factors to take into account in traditional marketing is the positioning of the brand and the product, in order to look for the differentiation before its competitors and to make a hole in the market. When we talk about luxury fashion, this positioning does not exist, since luxury is not comparative, luxury fashion has to seek to be unique in the market, not to compare with any other or seek to position itself. Luxury is never superlative comparative. This rule is essential in the strategies of luxury fashion brands.

b) Luxury does not have to respond to the increase in demand. Traditional marketing strategies, with increased demand will automatically respond to the increase in production, since if it does not respond to demand, it will lose sales and prestige, also creating tension in customers. However, luxury fashion does not have to respond to the increase in demand in this way, since luxury responds to a dream, not to a need, which has to expand its market globally and thus its production, but never produce in mass or as a reaction to the increase in demand, thus acting would lose its essence, its uniqueness and its value in the perspective of its customers who seek to live their dreams through luxury and the brand.

c) Luxury fashion has to dominate the customer, not arrogantly, but luxury brands, unlike the rest, must be those who take the role of advisers, educators and social 
guides, the customer who buys luxury fashion is buying identity, culture, art, social status, etc.

d) Make it difficult to buy from customers. Luxury has to be something that the customer must have earned, the more difficult the access to a luxury piece, the more desirable it will be for its consumer. The most used marketing strategies in luxury fashion to increase the desire of customers and make it difficult to purchase are the increase in the price of the product, the limited production of the product and the waiting in the delivery deadlines.

e) No USP (Unique Selling Proposition), this is another of the traditional marketing laws that are usually the most usual and important when it comes to promoting and publishing the brand. In the case of luxury fashion, there is no single selling proposition, the yearning comes first, with which advertising has to recreate that personalized desire of consumers.

f) Communicate to those who are not your target audience. Luxury satisfies the values of personal and social uniqueness, if a brand is only communicated to its target audience, the public inaccessible to these brands cannot recognize them, then loses its social value to its consumers. One of the most commonly used strategies for communicating luxury fashion to all audiences globally is by using their products for celebrities, appearing at global events such as the Oscars, for example.

g) Luxury sets the price and not the other way around. In luxury, price strategies are inverse to price strategies in traditional marketing. In luxury fashion a product is released to the market, and once you have an idea of the price by which it can be sold, you are charged a price. Over time, prices in luxury fashion will increase, as more demand, more price increase as luxury wins demand with the rise in prices and not the other way around.

h) Do not relocate factories. This strategy is key for a brand to remain in the luxury industry, as soon as a brand ceases to manufacture in its own country or relocate its factories to lower costs or for other convenience, ceases to belong to luxury.

i) Sell marginally on the internet. Internet sales increase year after year, new technologies and companies such as Net-a-porter show that this trend also has a place in luxury fashion, although you have to be very careful with e-commerce strategies, since selling their products online can break many of the anti-laws.

Although some people still need to see and feel the products at the catwalks and international fairs [15], the digital age offers possibilities that begin to influence the marketing of luxury goods and therefore in the trends of Marketing strategies in fashion luxury. For Bastien and Kapferer [2] the most important trends today are three; Business consolidation, digital strategies and globalization. With the company consolidation are grouped the financial statements of two or more companies that are legally independent. This is a strategy is being trend among the leading luxury brands in the market, groups such as LVMH (Louis Vuitton Moët Hennessy), Kering (The group of companies to which Gucci, Bottega Veneta, Saint Lauren, Alexander McQueen, among others belong. .) Are joining YOOX Group, the group of digital companies in the world of fashion and luxury fashion, which have recently added to the group the genius of e-commerce Net-a-porter. 
With the strategy of consolidation of companies, these tax groups that owns the leading brands of the market, intend to become with emerging brands with the objective of making a strong growth and performance of them.

Digital and mobile strategies in luxury fashion marketing are essential to innovate communication and even sales and distribution systems. What only a few years ago seemed impossible, since it seemed that e-commerce would never reach luxury, new technologies and above all, the use of mobile devices have challenged it and even today art galleries and houses Auctioned off as Christie's have joined e-commerce to sell and auction their products.

The digital marketing strategies most used by fashion are the online presence strategies through website and social networks [2] through mobile devices that promote interaction with the user and video marketing strategies that use the videos to generate rapprochement and Interaction with the spectators and participate in the development of the storytelling of the company.

\subsection{Digital Marketing and storytelling}

The principle of "storytelling" is one of the key strategies in digital and mobile marketing, this principle is found in video marketing strategies, social media, events and exhibitions open to the public, which seek to interact with the public and show their history, Such as the \#series events that Louis Vuitton is carrying out each season in different cities [4] these strategies brands seek to show the processes of creation of their collections, the history of the brand, its founders, current workers, provenance Of their materials, show their parades and events, show the reality of the backstages, and a long etcetera. In marketing strategies, convincing consumers to join the brand journey is key, and this is what creates the "storytelling" principle [16].

In addition to inviting consumers to travel the brand, digital and mobile marketing strategies through blogs, digital forums and social networks create a parallel communication with their consumers, not only communicate but also consumers are part of this communication, Interacting and creating viral Marketing in social networks, talking with their consumers, making them part of the brand world [16].

\section{$4 \quad$ Results of the Research}

The selection of the brands analyzed, as mentioned at the beginning of this research, was carried out taking into account the results of the Brandz 2015 ranking of Milldward Brown [3], which presents the most valued brands at international level, completing this selection with a study of the brands with more interaction in social networks between January and June of 2015 published by Digital Luxury Group (DLG) [4], this data was contrasted by the number of followers that have in social networks like Instagram and Facebook for thus To get a list of the brands with more mobile interaction and followers: Prada, Chanel and Louis Vuitton. From this point a research was carried out on its history and communication tools both off line and on line, study that we present summarized below. 


\subsection{Prada}

Prada was founded in 1931 by Mario Prada in Italy. The brand positioned itself as one of the leading brands in luxury accessories in Italy, the key to its immediate success was to open the first store in the luxury building in Milan that connects Piazza del Duomo with Piazza della Scala, the Galleria Vittorio Emanuelle .In addition to the location of the first store, the quality of fabric and leather in its products, which were aimed at meeting the needs of the elite consumers of the time, helped the Italian royal family show interest in Prada, and thus the company was designated as the official brand in travel accessories of the royal family [17].

The evolution that brought Prada to what it is today was thanks to Miuccia Prada, the granddaughter of the founder Mario Prada, who took over the company in 1978 and after doing a study of the business model understood the changes that were needed to stand out among the brands of luxury fashion [17].

After more than 30 years under the command of Miuccia, you can see four key phases that have been responsible for the success and value of the brand today, being one of the leading brands in the luxury market.

The first phase consisted in recognizing the need for brand distinction. Miuccia knew the need to offer a radical and different proposal within the luxury fashion sector, so in 1980 she started working on a collection of black nylon handbags, suitcases and backpacks. These products were distinguished by their design and discreet recognition of the brand, in addition to being technologically advanced, differed from the designs loaded and with excess brand recognition [17]. The utilitarianism of Miuccia combined with sophistication, technology and controlled extravagance, quickly managed to differentiate Prada from other brands in the luxury sector.

The second phase consisted of using the critical elements to create the internationalization of the brand. Together with her husband, Patrizio Bertelli, they began securing retail accounts at the leading stores and boutiques in the United States and Europe, which gave them the opportunity to secure an interest and knowledge of the brand by international consumers at a risk And minimum cost. They continued with the redesign of the shop in Milan, followed by the opening of the store in New York in 1986, followed by Paris, Madrid and London. And so began the globalization of business.

In the third phase, Prada's aspirations and ambitions are evident, when it acquired $9 \%$ of the shares of Gucci, one of the leading Italian brands in the same sector, in 1998. The company never intended to gain control of Gucci, but was participating in an alliance in defiance of the LVMH group, thus ensuring Gucci. Prada sold its shares to LVMH the following year in excess of \$ 100 million. His aspirations to create an international group of luxury brands, his decision on the acquisition of The Car Shoe and Church in 1999, in addition to the independence of the Miu brand, are the Strategies acted by Miuccia to give shape to the luxury conglomerate of the mark [17].

In the fourth phase Prada continues with the stretching strategies opening market in the cosmetics industry, perfumes and accessories such as sunglasses. Digital and mobile marketing strategies are also essential in the process of brand consolidation, and Prada joins digital marketing strategies through storytelling tactics on digital platforms, mainly through interaction with the public through social networks Through 
mobile devices, or with the use of celebrities and bloggers to influence their target audience, and differentiate themselves from most of the leading luxury brands in the market, Prada joins e-commerce, offering online sales of its products From its website.

\subsection{Chanel}

Chanel was founded in 1909 by Gabriel Bonheur "Coco" Chanel in France. Chanel today produces haute couture fashion, fashion ready to wear, accessories, jewellery, watches, perfumes and cosmetics. Chanel is recognized as one of the companies with the highest value in luxury fashion, the company remains owned by Alain and Gerard Wertheimer, great grandchildren of Coco Chanel's partner, Pierre Wertheimer, continues to belong to the family roots of the founder.

Chanel is represented by her iconic products, black dress, No.5 perfume and jacket suit, but the core of her identity is the same founder of the brand, Coco Chanel, she plays a crucial role in DNA and values of the brand. Chanel ventured into different areas of the luxury fashion industry, gradually becoming one of the leading brands. The success of the brand is based on its rich heritage, an astute assessment of the markets and their marketing strategies [18].

To get closer, to attract and connect with her audience, Chanel uses storytelling in all its forms, especially using the history and image of its founder and the current creative director of the brand, Karl Lagerfeld. It also makes use of the support of highly influential celebrities in the different types of consumers in which it is targeted, among these celebrities include Nicole Kidman, Blake Lively, Kiera Knightly, Audrey Tatou and Kristin Stuart.

The stretch brand has been used by Chanel since its inception, when it began to create hats, to quickly move to the fashion of clothing, accessories, perfumes, cosmetics, jewellery and watches.

Digital marketing stands out highly in the marketing strategies of the brand [18] Chanel has not ventured into e-commerce, makes use of social networks, website and blog to approach and connect with the public, offering information of history The creation of their collections, the presentation of their haute couture lines, events, the history of their creative director, and so on.

The creation of videos as a digital strategy in Chanel is one of its strong strategies to articulate the identity of the brand in a narrative way, Karl Lagerfeld, has directed different mini videos that revitalize the image of the brand [18]. These mini videos are arranged chronologically in a micro-site based on content within the brand's website, which invite consumers to discover the history and evolution of it, each of the videos creatively inform the steps Company history, emphasizing the founder and identity of the brand, Coco Chanel. The content of the videos is concise, inspirational and emotional, connects directly with the emotions of consumers. One of the videos "Cocoinside-chanel" reveals the story of the founder and how she reinvented herself, from being an orphaned young woman to becoming an independent and successful woman.

The narrative accompanied by good content that Chanel offers in each of its videos are the key to the success of its digital marketing strategies, these create a deep under- 
standing of the brand in its consumers and at the same time provides motivation in the decision to buy their products. The videos also invite to be shared by their consumers in social networks, creating virility to the campaign in different online platforms, by the inspiration that these provide to the consumer and the revolutionary spirit of the creator of the mark. Consumers by sharing information among their friends and acquaintances through the mobile phone, makes them feel that they are that or are part of what they share in the network.

Chanel also has marketing strategies related to the price of its products, chronologically increasing brand value. It uses here one of the anti-luxury marketing laws, on the one hand, it sets the price of its products without the customer being the one who dominates this factor, on the other, the increase of prices increases the inaccessibility and exclusivity of its products, Creating brand value.

A study by Baghunter, [19] focused on Chanel's "Medium classic flap bag", which has been on the market since 1955, gives us a clear and concise view of Chanel's price structure strategies in recent years

\subsection{Louis Vuitton}

Founded in 1821 in Compte, France and began creating high-quality travel trunks and leather accessories, in 1852 Napoleon III selected Louis Vuitton as the official travel and packaged trunks manufacturer of the Queen. Its first leather shop was opened in Paris in 1854, when Louis Vuitton already had the good reputation on the part of the queen [20]. In 1885 it began its global expansion and opened its first store in London, and in 1890 invented the exclusive lock for his trunks of travel.

In 1987 he implemented the company consolidation strategies, acquiring the Veuve Clicquot group, creating and shaping the LVMH group (Louis Vuitton Moet Hennessy).

With the entry of Mark Jacobs as creative director in the company in 1998, Louis Vuitton went into luxury fashion, creating trends in the world of luxury. The philosophy of Louis Vuitton is to create a contrast between tradition and modernity, tradition in combination with modernity, proven innovation, excellence and creativity are proof of the philosophy of Louis Vuitton. Its slogan "The art of traveling is the art of living well", demonstrates its fidelity to its identity and how the brand continues to have a strong connection with its heritage, despite the fact that it is years that separate it from its exclusive sale of products of travel [20].

Storytelling is present in all the marketing strategies of Luis Vuitton, through different platforms and mobile devices connects with its audience through the history of the brand, its commitment to the quality of its products and its particular manufacturing processes, reaching the Public in an emotional way. Events like "The series" where Louis Vuitton organizes exhibitions open to the public in strategic cities of the world during a certain period of time. In the exhibitions presents the seasonal collection and opens the door to the public making him a participant in the history of the brand and collection. In "Les Journées Particulieres", an event in which Luis Vuitton highlights the craftsmanship of its products. 
Louis Vuitton invites the public to know the manufacturing processes of their products and the history of them, how the production processes have evolved, and so on. Digital marketing is key in the creation of storytelling and interaction with customers, through online platforms and mobile devices, through the use of bloggers and social media, offer customers the visualization of the history of the brand and its products.

Basic digital marketing strategies in Louis Vuitton consist of having presence in social networks, where the brand interacts, informs and surprises its customers. To capture the attention and reputation among one of the most complicated audiences, the millennials, Louis Vuitton uses celebrities with great influence in these audiences, as in its last campaign Series 5, where it chooses the image of Selena Gómez like nucleus of the campaign.

\section{Conclusions}

Conclusions are detailed and classified by the information presented in the different sections and contrasted with the information obtained in the different interviews with professionals of the sector.

\subsection{Globalization as responsible for the growth of the value of the fashion industry}

The effect of globalization and the emergence of emerging markets are one of the factors responsible for the increase experienced by the fashion industry in recent years. Leading brands in the market have been able to anticipate the changes and to include emerging markets in their strategies, as the number of "High Net Worth Individuals" in the world has increased and globally expanded with global economic expansion. People with incomes of more than 100,000 million dollars a year. Brands take this effect into account, and reinvent themselves in their marketing and business strategies to adapt to and approach emerging markets eager to consume luxury fashion.

"One of the fundamental requirements in the search for new employees is their relationship with other countries, if this person has travelled, speaks languages, has contacts abroad, and so on. People who speak Chinese or Arabic, or have lived in the country, or show knowledge of different cultures. These characteristics are very important and we take them into account when deciding between one person or another. The luxury industry is directly related to the global culture and this knowledge is essential. "(Interviewee 2, Human Resources Manager Christie's, London).

"Points of sale, social networks, websites, events ... no matter the channel, we always try to get as much information as possible when interacting with customers or visitors. This helps us to understand our consumers and take the most appropriate strategies in each comment, especially to consumers in emerging countries like China, Korea or Russia, with cultures and buying habits very different from European customers." (Interviewed 4, Marketing Executive at Hackett, London) 


\subsection{Digital Marketing and the relationships of brands with influencers}

We can say that digital and mobile marketing are the most used tool by leading luxury brands in the market, although many of them still resist selling online. Digital marketing is evident in each strategy that help brand awareness, consumer interaction and buying motivations. Through digital marketing brands, it is possible to communicate the history of the brand through storytelling loaded with good stories and good content. Its relationship with the most influential bloggers and instagramers in luxury fashion consumers is another of the digital marketing strategies they carry out to influence their consumers through social networks and mobile telephony.

"I am very faithful to my followers and to myself, this I think is what has helped me to get here. There are many proposals that I receive from different brands and companies to promote them, but before making a decision, I always study carefully that the brand, garment or accessory go with my style, even if they are well-known brands or are offering me a Good deal, I do not accept if it does not go with my style, my blog and my followers."(Interviewee 1, Fashion Blogger, UK)

"Most customers when they arrive at the store know the product features or have a very clear idea of what they want, because they have looked for information on the internet before coming to buy. Many still want to give you more information and enjoy the care they receive for us, but the difference between customers who have sought information and those who are not, are more demanding, especially the younger ones. "(Interviewed 3, Personal shopper in Selfridges, London).

Digital marketing strategies are the perfect tool to communicate, give information and motivate the target audience to make the purchase. On the other hand, store employees must be highly trained and know their products, as these consumers have knowledge of the product and bad information given in store can screw or disappoint the consumer.

"Video marketing is one of the best marketing strategies at the moment, the mini videos shared between different digital and mobile platforms are being a success for the launch of new products or brand information. The public accepts them very positively and viral marketing is almost guaranteed with the creation of these mini videos. "(Interviewee 4, Marketing Executive in Hackett, London).

\subsection{The Brand as an integral part of the luxury product}

Brand strategies in luxury fashion are imperative. Brands are an integral part of luxury fashion, so much so that we can conclude that today there would be no luxury without the brands. In their strategies, brands have to define the identity of the brand, what makes it unique and exclusive, consumers have to connect emotionally and psychically with it. We have seen that each of the leading brands in the market communicate with their customers and use storytelling to reach their customers emotionally and convey to them the essence, identity, history and values of the brand.

"The essence of the brand is present in each of our campaigns. It is the engine of the campaigns, the ideas and inspirations on the part of the team arise from the history and evolution in the time of the brand, if we are planning the launch of a new cam- 
Paper-Storytelling and Social Networking as Tools for Digital and Mobile Marketing of Luxury Fash...

paign, before carrying out we always ask ourselves the question where is the identity of the brand in this campaign? If we cannot answer this question, then the campaign needs to be rethought." (Interviewee 4, Marketing Executive at Hackett, London)

We have also seen how consumers decide the brand they want to buy and then choose the product, not the other way around.

\subsection{Millennials, the future consumers}

Millennials have grown up with digitalization and globalization, are less committed to brands, do not perceive a reality without Internet and are influenced more by the opinion of their friends than by professionals. Leading brands are using highly influential celebrities and bloggers in millennials, and are adapting ways to communicate with them through social networks and mobile devices.

"Young customers, between the ages of 20 and 30 are very clear about what they want when they come to the store, come with brand information and usually know the detail when a product is in season. On the one hand, they are easier, because knowing their style and having information of the brands and products, somehow already have covered your work, but it is more difficult to connect with them or know if they will buy again or not, I will I take a personal challenge and try to learn from them. Older consumers are more loyal, they want you to advise them, guide them and tell them what the trends of the season are. Many of my most loyal clients are between 45 and 55 years old. " (Interviewee 3, Personal shopper in Seldfridges, London).

\section{$6 \quad$ Limitations of the study}

We can conclude that although the present study sets some guidelines that describe the current strategies followed by some of the international luxury brands, a more extensive revision of the rest of brands identified as leaders in the sector will be necessary in order to know how they are carrying out its incorporation into the digital and mobile world.

In addition, a complementary study on the opinions of consumers of digital media and mobile device users will help to understand which of the strategies described are most effective in an audience that is increasingly eager for short-term information.

\section{$7 \quad$ References}

[1] Beverland, Michael (2004), Uncovering ‘theories-in-use' building luxury wine brands, European Journal of Marketing, Vol. 38 Nos 3/4, 446-66. https://doi.org/10.1108/0309056 0410518648

[2] Bastien, Vincent \& Kapferer, Jean-Noël (2012). The Luxury Strategy: Break the rules of marketing to build luxury brands. Philadelphia: Kogan Page.

[3] Ranking BrandZ "Las 100 marcas más valiosas de 2015", Disponible en: http://www.millwardbrown.com/BrandZ/2015/Global/2015 BrandZ Top100_Report.pdf 
Paper-Storytelling and Social Networking as Tools for Digital and Mobile Marketing of Luxury Fash...

[4] Luxury Daily Group (2015). Link: https://www.luxurydaily.com/louis-vuitton-reinterpretsad-effort-for-london-exhibition/

[5] Bomsel, O. (1995). L'industrie du luxe ou comment associer objets et repre'sentations (Luxury industry or how to combine objects and their representations), Annales des Mines - Re'alite's Industrielles, July-August, 14-20.

[6] Brun, Alessandro \& Castelli, Cecilia (2013). The nature of luxury: a consumer perspective, International Journal of Retail \& Distribution Management, Vol. 41 Iss 11/12, 823-847. https://doi.org/10.1108/IJRDM-01-2013-0006

[7] Phau, Ian \& Prendergast, Gerard. (2000). Consuming luxury brands: the relevance of the 'rarity principle', Journal of Brand Management, Vol. 8, 122-138. https://doi.org/10.1057/ palgrave.bm. 2540013

[8] Twitchell, James (2003). Living it Up: America's Love Affair with Luxury, Columbia University Press, New York, NY

[9] Quelch, John (1987). Marketing the premium product, Business Horizons, Vol. 30 No. 3 , 38-45. https://doi.org/10.1016/0007-6813(87)90035-8

[10] Kapferer, Jean-Noël; Klippert, Cindy; \& Leproux, Lara (2014). Does luxury have a minimum price? An exploratory study into consumers' psychology of luxury prices. Journal of Revenue and Pricing Management 13:1, 2-11. https://doi.org/10.1057/rpm.2013.34

[11] Wong, Nancy \& Ahuvia, Aaron (1998). Personal taste and family face: Luxury consumption in Confucian and Western societies, Psychology \& Marketing, Vol. 15 No. 5, 423432. https://doi.org/10.1002/(SICI)1520-6793(199808)15:5<423::AID-MAR2>3.0.CO;2-9

[12] Vigneron, Franck \& Johnson, Lester (2004). Measuring perceptions of brand luxury, The Journal of Brand Management, Vol. 11 No. 6, 484-506. https://doi.org/10.1057/palgrave. bm. 2540194

[13] Tsai, Shu-Pei (2005). Impact of personal orientation on luxurybrand purchase value: an international investigation, International Journal of Market Research, Vol. 47 No. 4, 429454.

[14] Wiedmann, Klaus; Hennigs, Nadine \& Siebels, Astrid (2009). Value-based segmentation of luxury consumption behavior, Psychology and Marketing, Vol. 26 No. 7, 625-651. https://doi.org/10.1002/mar.20292

[15] Hägg, Claes \& Preiholt, Håkan (2006). Growth opportunities in luxury goods and real estate, Journal of Fashion Marketing and Management: An International Journal, Vol. 10 Iss 1, 114-119. https://doi.org/10.1108/13612020610651169

[16] Greenhill, Duke (2011) 4 Pillars of Digital Marketing for luxury brands. Disponible en: http://mashable.com/2011/11/29/luxury-marketing-digital/ - ksDsffWwFuq0

[17] Moore, Christopher \& Doyle, Stephen (2010) The evolution of a luxury brand: the case of Prada, International Journal of Retail \& Distribution Management, Vol. 38 Iss: 11/12, 915927, https://doi.org/10.1108/09590551011085984

[18] Mo, Estelle (2015) Master of Narrative: A case study of Chanel's Digital Marketing Strategies Disponible en: https://estellemo.wordpress.com/2015/09/25/master-of-narrative-acase-study-of-chanels-digital-marketing-strategies/

[19] Baghunter (2016) Chanel Bag Values research studies. Disponible en: https://baghun ter.com/pages/chanel-bag-values-research-study

[20] Haddas, Noy (2015) Louis Vuitton case study. Disponible en: https://prezi.com/k6o nivfbygkg/copy-of-louis-vuitton-case-study/. 
Paper-Storytelling and Social Networking as Tools for Digital and Mobile Marketing of Luxury Fash...

\section{Authors}

Dr. Zahaira Fabiola González Romo is a Lecturer at the Faculty of Business and Communication at the University of Vic, a Lecturer at the International University of Catalonia, and also teaches at the Multimedia Technology Center of the Polytechnic University of Catalonia. She works as a consultant at the Universitat Oberta de Catalunya and as a Lecturer also at the University School of the Mediterranean.

Dr. Irene García-Medina is a Lecturer in Marketing at the Glasgow Caledonian University. She has a PhD in Marketing and another PhD in International Relations, She has published numerous articles in top ranking international journals.

Noemí Plaza Romero is in charge of Marketing and Partnerships UK \& Ireland in the Uber multinational, assistant in the Marketing department at Christie's UK, responsible for the development of marketing strategies at Harley Care Services Ltd, and account executive at Hotel Cafe Royal.

Article submitted 31 July 2017. Published as resubmitted by the authors 12 September 2017. 